\title{
Characterization of the Shark Myelin Po Protein
}

\author{
L. Rotenstein ${ }^{\mathrm{a}} \quad$ K. Herath ${ }^{\mathrm{a}} \quad$ R.M. Gould ${ }^{\mathrm{b}}$ M.E. de Bellard ${ }^{\mathrm{a}}$ \\ ${ }^{a}$ California State University Northridge, Biology Department, Northridge, Calif., ${ }^{b}$ Department of Anatomy and \\ Cell Biology, University of Illinois at Chicago, Chicago, III., USA
}

\section{Key Words}

Development • Evolution nervous systems • Myelin • Shark • Developmental evolution • Elasmobranch • Embryology • Po protein

\section{Abstract}

Myelin, the insulating sheath made by extensive plasma membrane wrapping, is dependent on the presence of highly adhesive molecules that keep the two sides of the membrane in tight contact. The Po glycoprotein (Po) is the major component of the peripheral nervous system (PNS) myelin of mammals. The exact role that Po protein has played in the evolution of myelin is still unclear, but several phylogenetic observations suggest that it is a crucial component in the development of myelin as a multi-lamellar membrane structure. Sharks, which appeared in the fossil record about 400 million years ago, are the first fully myelinated organisms. In this study we investigated the expression pattern of shark myelin Po to suggest a way it might have played a role in the evolution of myelin in the central nervous system. We found that sharks have more than two isoforms (32, 28 and $25 \mathrm{kD})$, and that some of these might not be fully functional because they lack the domains known for Po homophilic adhesion.
\end{abstract}

Copyright $\odot 2008$ S. Karger AG, Basel
(C) 2008 S. Karger AG, Basel

Accessible online at: www.karger.com/bbe

\section{Introduction}

Myelin, in its compact form, is the insulating sheath that covers axons in the central and peripheral nervous system, allowing rapid nerve conduction. It consists of glial plasma membrane tightly wrapped around axons and devoid of any cytoplasmic fluid. Myelin compaction is dependent on the presence of highly adhesive molecules that keep the two sides of the membrane in tight contact. The Po glycoprotein (Po) is the major component of the peripheral nervous system (PNS) myelin of mammals. This protein has been shown to bind in a homophilic manner to an opposing membrane and is the molecule responsible for myelin compaction [D'Urso et al., 1990; Filbin et al., 1990; Giese et al., 1992]. The exact role that Po protein has played in the evolution of myelin is still unclear, but several phylogenetic observations point to it as a crucial component in the development of myelin as a multi-lamellar membrane structure. For instance, the Agnatha group, which lacks compact myelin, already shows Po immunoreactivity [Kirschner et al., 1989; Waehneldt, 1990]. However, although no Po has been reported among the sequenced genomes of sea squirt (Ciona), lancelet (Amphioxus) or any other invertebrate [Gould et al., 2005], recent analysis from Amphioxus libraries suggests that at least Po is present in the first chordates [Sauka-Spengler et al., 2007; Dr. Sauka-Spengler, Caltech, personal communication]. Also, in elasmo-

M.E. de Bellard

California State University Northridge

Biology Dept., MC 8303, 18111 Nordhoff Street

Northridge, CA 91330 (USA)

Tel. +1 818677 6470, Fax +1 818677 2034,E-Mail maria.debellard@csun.edu 
Human Po

Mouse $\mathrm{PO}$

Chickēn_Po

Zebrafish Po

Trout Po

Shark_Po

Human Po

Mouse_Po

Chickēn Po

Zebrafish Po

Trout_Po

Shark_Po

Human_Po

Mouse Po

Chickēn Po

Zebrafish Po

Trout Po

Shark_Po

Human Po

Mouse Po

Chickēn Po

Zebrafish Po

Trout_Po

Shark_Po

Human Po

Mouse_Po

Chickēn Po

Zebrafish Po

Trout_Po

Shark_Po
MAPGAPSSSPSPI LAVLLFSSLVLSPAQAIVVYTDREVHGAVGSRVTLHCSFWSSEWVSD MAPGAPS SSPSPI LAALLFS SLVLSPALAIVVYTDREIYGAVGSQVTLHCSFWSSEWVSD MALGAIGDGRLLLLLVGLLSASGPSPTLAI HVYTPREVYGTVGSHVTISCSFWSSEWISE MLS------VLALTSVVLLGIAS-QSTALVVNTDSEKHALVGSDVRLSCSFFSWQWTSP MLT-------ILALASVILLGIVPQQSEAIVIYTGWERHALVGSDIRLSCSFFSWRWTSD MFRDLKP--AYLFCCSVLYAFSVLRPSQGISVSTHHNLHKTVGSDVTLYCGFWSNEYVSD

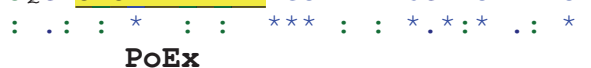

DISFTWRYQPEGGRDAISIFHYAKGQPYIDEVGTFKERIQWVGDPRWKDGSIVIHNLDYS DISFTWRYQPEGGRDAIS IFHYAKGQPYIDEVGTFKERI QWVGDPRWKDGS IVIHNLDYS DISYTWHFQAEGSRDSISIFHYGKGQPYIDDVGSFKERMEWVGNPRRKDGS IVIHNLDYT EVSFTWHYRPDGAKDAIS IFHYGGGEAYPANKGPFQNRLEFVGNP SRRDGS I LIKNLDFG DVTFSWSYRPDGARDAIS IFHYTGGAPYVDNKGP FRDRLEFVGNPGRRDGS I LLKNLDYG LTTLSWRFRPDNSRDIISIFHYGNGVPYIEKWGQFRGRVEWVGDISKHDGS IVIRNLDYI

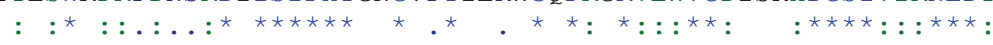

DNGTFTCDVKNPPDIVGKTSQVTLYVFEKVP-TRYGVVLGAVIGGVLGVVLLLLLLFYVV DNGTFTCDVKNPPDIVGKTSQVTLYVEEKVP-TRYGVVLGAVIGGILGVVLLLLLLFYLI DNGTFTCDVKNPPD IVGKSSQVTLYVLEKVP-TRYGVVLGS I IGGVLLLVALLVAVVYLV DNGTFTCDAKNPPD IGGHPSTIRLLVEEKVP-VQAGVITGS I IGVVLGLLILVVA IYYLM DNGTFTCDAKNPPDIVGRAS SVRLLVFEKVP-IOAGVITGSI I GAVLGLLLLIVVIYYLM DNGTFTCDVKNPPDVVGTSSDVHLTVYDKI PPVGAGVVSGAI IGTFLGI ILLIVGGLYLF

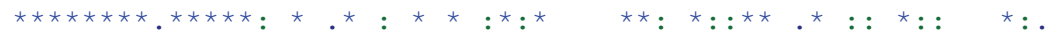

RYCWLRR----QAALQRRLSAMEKGKLHKPGKDASKRGRQTPVLYAQCWTTAEAPKLSVR RYCWLRR----QAALQRRLSAMEKGRFHKS SKDSSKRGRQTPVLYA-MLDHSRSTKAASE RFCWLRR----QAVLQRRLSAMEKGKLQRSAKDASKRSRQPPVLYA-MLDHSRS AKAAAE

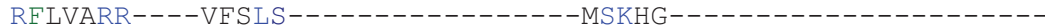

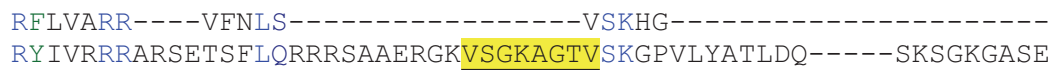

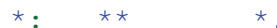
PoCy1

RRPRGW-GSLARIRNSG KKSKGL-GESRKDKK-KKSKGAPGEARKDKK-KKGKGKEGSQQKQRI-KKGKGKEGSQQRQ---KKSK--LSESKRDKK--

$:: \quad: \quad$ :

PoCy2

Fig. 1. Myelin Po sequence alignment and analysis. Sequences from Genbank were aligned via the program of ClustalW. Sequences chosen for peptide antibody preparation are underlined. PoEx sequence shares some similarity with rodent Po. PoCyl sequence has no homology with other Po proteins and PoCy2 corresponds to the cytoplasmic domain of Po which is highly conserved among most of the species we looked. The consensus key for the amino acids sequences is: * (single asterisk, fully conserved residue), : (colon, conservation of strong groups), . (black dot, conservation of weak groups) and 'blank' (no consensus).

branchs and teleost fish, Po is the major myelin protein component not only in the PNS but also in the central nervous system (CNS) [Waehneldt et al., 1986; Saavedra et al., 1989; Stratmann and Jeserich, 1995]. These observations have suggested to researchers that the transition between non-compact myelin to compact myelin parallels the appearance of Po in evolution.
Cloning shark Po revealed that this glycoprotein is conserved $(\sim 46 \%)$ throughout vertebrate evolution (fig. 1) and is the product of a single mRNA transcript [Waehneldt et al., 1987; Saavedra et al., 1989; Stratmann and Jeserich, 1995]. Furthermore, the cloning of a Po-like glycoprotein from trout CNS shows that it has about 50\% sequence homology with shark and rat Po and also results 
from one mRNA transcript [Stratmann and Jeserich, 1995]. Indeed, Po in elasmobranchs also carries the same HNK-1 carbohydrate epitope as Po in mammals [Zand et al., 1991].

In mammals only one Po isoform has been detected [Uyemura and Kitamura, 1991], whereas in sharks [Tai and Smith, 1983; Nunn et al., 1987; Saavedra et al., 1989] and chickens [Nunn et al., 1987] at least two isoforms are present. Bony fishes also seem to have two Po-like proteins (IP1 and IP2) [Stratmann and Jeserich, 1995]. But the true identity of these Po-like proteins in shark has yet to be defined by methods more sophisticated than merely the determinations of molecular weight and type of glycosylation.

The value of studying these well known myelin proteins in sharks derives from the position that cartilaginous fish hold in the evolution of myelin. Sharks, which appeared in the fossil record about 400 million years ago, are the first fully myelinated organisms [Bakay and Lee, 1966; Waehneldt, 1990]. Before them, other organisms, such as lampreys and earthworms, have glial membrane loosely wrapped around axons, but not true compact myelin [Bullock et al., 1984; Waehneldt et al., 1987]. Cartilaginous fish are considered to be the first ones to have compact myelin [Kitagawa et al., 1993]. All this implies that in the evolution of myelin several factors converged: the presence of glial cells, presence of adhesive molecules and evolutionary advantage over non-compact myelin. Therefore, studying the spatio-temporal expression of the major myelin protein in shark will help in our understanding of the evolution of myelin. In this study we set out to investigate the expression pattern of shark myelin Po as a way of understanding its contribution to the evolution of myelin in the central nervous system.

\section{Materials and Methods}

\section{Po Antibodies}

Rabbit antibodies against Po were raised by injection of purified bovine Po with Freunds adjuvant (RabA antibody) or of Po peptides with Titer-Max (peptide antibodies). The polyclonal antibody PoCy2, that recognizes the cytoplasmic domain of mouse Po, has been described elsewhere [Gould et al., 1995]; it detects the full length Po protein. For the anti-Po peptide antibodies, two sequences from shark Po [Saavedra et al., 1989] and one from rat Po protein [Lemke et al., 1988] were selected to raise peptide antibodies (fig. 1). In order to raise antibodies that will be specific for shark only, we chose sequences where the similarity between shark and mouse was the lowest. Thus Western blots using PoEx or PoCy1 on rat myelin did not show any cross-reactivity, confirming that these new antibodies are specific for shark Po.
Shark Nervous System Preparation

Shark nervous system regions from adult spiny dogfish (Squalus acanthias L. 1758) from Woods Hole Marine Biological Labs $(\mathrm{MBL})$ were rapidly dissected and frozen on dry ice. Following the procedure reviewed and approved by the Animal Welfare Committee at MBL, the animals were anesthetized in 1:10,000 parts of MS222 in sea water until they were insensitive to touch and were then killed by decapitation. The following regions were dissected: telencephalon (olfactory bulbs and cerebral hemispheres), diencephalon (epiphysis), mesencephalon (optic tectum), metencephalon (cerebellum), myelencephalon (medulla), and trigeminal nerves [Wischnitzer, 1993; Butler and Hodos, 2005]. Shark embryos collected from pregnant Squalus acanthias were staged based on fetal length as described in Ballard for shark embryos that are fully developed, although not yet fully grown [Ballard, 1993]. We collected and immediately froze brains from 4.0, 4.4, 9, and $22 \mathrm{~cm}$ embryos. Crude membrane fractions were prepared by homogenizing each region in 4 volumes of $1 \times$ SDS Laemmli sample buffer (2\% SDS, $10 \%$ Glycerol, $62.5 \mathrm{~mm}$ Tris; pH 6.8) in the presence of protease inhibitors $(1 \mu \mathrm{g} / \mathrm{ml}$ leupeptin, $2 \mu \mathrm{g} / \mathrm{ml}$ antipain, $10 \mu \mathrm{g} / \mathrm{ml}$ benzamidine, $1 \mu \mathrm{g} / \mathrm{ml}$ pepstatin, $1 \mu \mathrm{g} / \mathrm{ml}$ aprotinin, and $100 \mu \mathrm{M}$ PMSF). The protein content in each homogenate was estimated with a protein assay kit (Bio-Rad). Aliquots of the homogenates (depending on the figure, the amounts ranged between 2 and $10 \mu \mathrm{g}$ of total protein in a $50 \mu$ l volume) were loaded onto $12 \%$ polyacrylamide minigels (which have a $4 \%$ stacking gel to enhance protein resolution) in the presence of $1 \mu \mathrm{l}$ of $\beta$ mercaptoethanol and following electrophoresis (stacking gel run at $70 \mathrm{~mA}$ and resolving gel at $35 \mathrm{~mA}$ ), transferred to polyvinylidene fluoride (PVDF) membranes (at $0.6 \mathrm{~A}$ for $18 \mathrm{~h}$ at $4^{\circ} \mathrm{C}$ ) in the following transfer buffer conditions: $50 \mathrm{mM} \mathrm{Na}_{2} \mathrm{HPO}_{4}$ (anhydrous), 2 mM EDTA, $0.025 \%$ SDS that was buffered to $\mathrm{pH} 5.5$ with concentrated $\mathrm{HCl}$. Blots were immunostained with 1:3,000 dilutions of each different antibody. Shark Po was detected by secondary anti-rabbit antibody coupled either to alkaline phosphatase or horseradish peroxidase $(1: 20,000)$, and visualized by BCIP/NBT or ECL following manufacturer instructions (KPL), respectively.

\section{Myelin Preparation}

Myelin was isolated from the brains of spiny dogfish (S. acanthias) by conventional procedure [Norton and Poduslo, 1973]. The spinal cord was homogenized in $0.25 \mathrm{M}$ sucrose with protease inhibitors $(1 \mu \mathrm{g} / \mathrm{ml}$ leupeptin, $2 \mu \mathrm{g} / \mathrm{ml}$ antipain, $10 \mu \mathrm{g} / \mathrm{ml}$ benzamidine, $1 \mu \mathrm{g} / \mathrm{ml}$ pepstatin, $1 \mu \mathrm{g} / \mathrm{ml}$ aprotinin, and $100 \mu \mathrm{M}$ PMSF) and the concentration was brought up to $1.4 \mathrm{M}$ sucrose by adding $2.8 \mathrm{M}$ sucrose. The sample was overlaid with $0.85 \mathrm{M}$ sucrose and then $0.25 \mathrm{M}$ sucrose. The crude myelin was collected from the $0.25 \mathrm{M} / 0.85 \mathrm{M}$ interface after spinning at $40,000 \mathrm{~g}$ for $12 \mathrm{~h}$, osmotically shocked with water and spun again at 40,000 $g$ for $1 \mathrm{~h}$. The myelin pellet was solubilized in $1 \times$ SDS Laemmli's buffer (2\% SDS, 10\% Glycerol, 62.5 mm Tris pH.6.8).

\section{Endo F Treatment}

An $80 \mu \mathrm{g}$ sample of the shark (S. acanthias) spinal cord myelin fraction was boiled in $400 \mu \mathrm{l}$ of EndoF lysis buffer $(50 \mathrm{~mm}$ Tris $\mathrm{pH}$ 8.6, $25 \mathrm{~mm}$ EDTA, 0.1\% SDS and 0.5\% NP-40) in the presence of $2 \mu \mathrm{l}$ of $\beta$-mercaptoethanol. A cocktail of protease inhibitors (1 $\mu \mathrm{g} / \mathrm{ml}$ leupeptin, $2 \mu \mathrm{g} / \mathrm{ml}$ antipain, $10 \mu \mathrm{g} / \mathrm{ml}$ benzamidine, $1 \mu \mathrm{g} / \mathrm{ml}$ pepstatin, $1 \mu \mathrm{g} / \mathrm{ml}$ aprotinin, and $100 \mu \mathrm{M}$ PMSF) was added once the mixture cooled to room temperature, and $1 \mu \mathrm{l}$ 
(1 U/ml) of EndoF (Boehringer Mannheim) was added. The mixture was incubated overnight at $37^{\circ} \mathrm{C} ; 8$ volumes of acetone were added to precipitate protein, and the mixture was cooled for $2 \mathrm{~h}$ at $-20^{\circ} \mathrm{C}$. The proteins were pelleted by centrifugation at 5,000 $\mathrm{rpm}$ for $5 \mathrm{~min}$ in a Sorvall bench-top unit. Acetone was removed and once the precipitate was dry, the proteins were re-suspended in $30 \mu \mathrm{l}$ of SDS sample buffer and $5 \mu \mathrm{g}$ of total protein was run on the gel.

\section{Immunohistochemistry}

Chiloscyllium punctatum (Müller and Henle 1838) shark cases were harvested from the Long Beach Aquarium of the Pacific and the embryos collected at different developmental stages [Ballard, 1993]. The youngest collected embryos were $3 \mathrm{~cm}$ when they have developed most of their nervous system and they look like very small sharks; the oldest embryos were $10 \mathrm{~cm}$, a stage at which they show a lot of physical activity and look like their adult counterparts. Embryos were fixed in Carnoy's (70\% ethanol, 20\% formaldehyde and $10 \%$ glacial acetic acid) overnight at $4{ }^{\circ} \mathrm{C}$ and kept in $70 \%$ ethanol at $-20^{\circ} \mathrm{C}$ until histological preparation. In order to obtain good morphological results, the embryos needed very extensive dehydration steps (about 1 day per alcohol grade) and two full days in histosol for clearing. The tissues were then immersed in hot paraffin (McCormick Scientific Paraplast Plus) in a vacuum oven for 2 days before preparing the blocks and sectioning at $10-12 \mu \mathrm{m}$ thickness. Sections were rehydrated in histosol and a graded series of ethanol washes (histosol, 100, 90, 70, 50 and $25 \%$ ethanol washes in water) and then equilibrated in PBS (Dulbecco's) before blocking in PBS containing 10\% expired FBS and $1 \%$ Triton X-100 for $1 \mathrm{~h}$. Primary antibodies [rabbit polyclonal anti-myelin Po and anti-myelin basic protein; Gould, 1992] were added in a 1:500 dilution in PBS and slides were incubated overnight at $4^{\circ} \mathrm{C}$. After washing the sections in PBS for at least $20 \mathrm{~min}$, secondary antibodies (Alexa fluoroprobes conjugated to anti-rabbit or anti-mouse IgG, Invitrogen) were added for $30 \mathrm{~min}$ and washed in PBS for immuno-fluorescence visualization and coverslipped with Permount. Pictures of sections were taken using Axiovision LE software (Zeiss ${ }^{\mathrm{TM}}$ ) with an AxioCam black and white camera attached to a Zeiss AxioimagerAl upright fluorescent microscope and assembled into figures 7 and 8 using Adobe Photoshop 7.

\section{Results}

\section{Shark Po Antibodies Recognize Different \\ Isoforms of Po}

When the antibody that recognizes the full-length Po (RabA in fig. 2) was used in a Western blot of purified shark myelin, two major protein bands were observed. These bands match the molecular weights of the two Po isoforms (28 and $32 \mathrm{kD}$ ) previously reported for shark [Saavedra et al., 1989]. A smaller band of lower-molecular-weight $(25 \mathrm{kD})$ protein, not strongly stained, was also apparent. This band has not been previously reported for shark Po.

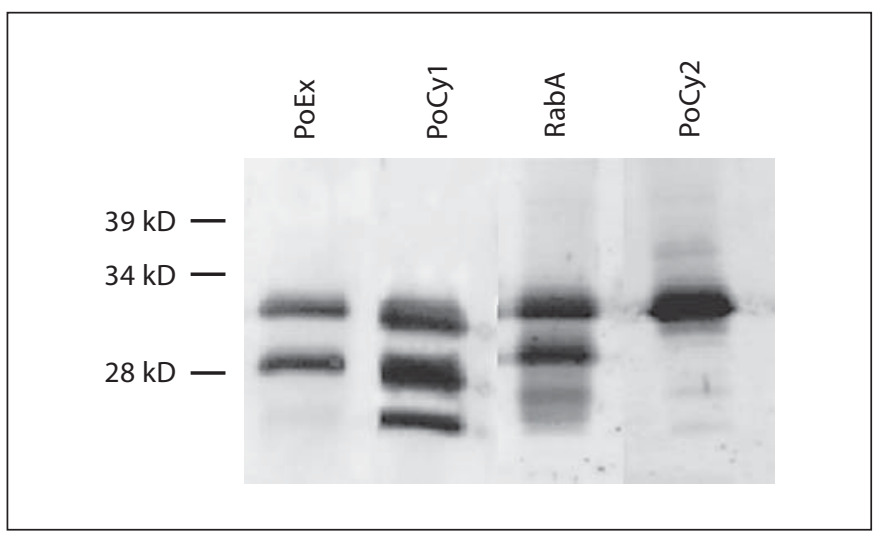

Fig. 2. Shark myelin Po isoforms. Western blot of purified shark myelin $(5 \mu \mathrm{g})$ showed several isoforms for Po. An antibody raised specifically to the shark cytoplasmic region (PoCyl) shows three bands for Po, whereas antibodies to the extracellular domain (PoEx) or a polyclonal antibody raised against purified Po (RabA) showed two strong bands and a fainter one. The antibody raised against the highly conserved cytoplasmic end of Po showed only one band. A total of $4 \mu \mathrm{g}$ of protein from purified myelin was loaded on each lane.

Immuno-detection using PoCyl in a sample from the same purified shark myelin revealed three prominent bands at apparent molecular weights of 25,28 and $32 \mathrm{kD}$ (fig. 2). This peptide antibody, specific for the cytoplasmic domain of shark Po, recognized the same two proteins previously observed with an antibody that recognizes full-length Po as well as a third isoform that matches the smaller band seen in that same Western blot. A Western blot with the PoEx antibody, raised against the N-terminus sequence of shark Po, showed only the two major 28 and $32 \mathrm{kD}$ protein bands. The lack of detection of the smaller $25 \mathrm{kD}$ band with this antibody suggests that this Po isoform is missing at least part of the corresponding $\mathrm{N}$-terminus peptide sequence from its extracellular domain.

The Western blot with PoCy2 antibody detected only the major band at $32 \mathrm{kD}$ (fig. 2). This peptide antibody corresponds to the $\mathrm{C}$-terminus of rat $\mathrm{Po}$, and is $65 \%$ homologous to the shark Po C-terminus. The fact that PoCy 2 did not detect the 25 and $28 \mathrm{kD}$ protein suggests that these two protein bands are different isoforms of shark Po that lack this end terminus region.

Our finding of several isoforms in the CNS from shark with different truncations has several explanations: that there has been some proteolytic degradation during sample preparation; or that they are due to endogenous proteolytic intermediates present in the lysosomes. The pos-

Brain Behav Evol 2008;72:48-58 
sibility that protein degradation took place during the myelin preparation and that it can account for the presence of several protein isoforms with decreasing molecular weights can be disregarded because all the procedures were performed with freshly dissected tissues and these were kept at $4^{\circ} \mathrm{C}$ and in the presence of suitable amounts of protease inhibitors. Second, we did not see any changes in the molecular weight of the major band or an enrichment of the lower band when the lysates were purposively left overnight at room temperature before running them on a gel (data not shown). Third, these gel patterns have been consistent and reproducible under many experimental conditions, no matter which method of sample preparation (to corroborate the uniqueness of these isoforms, we also ran the proteins under non-denaturing conditions, without $\beta$-mercaptoethanol) or the antibody used in the Western blot. The second possibility was that the Po isoforms found in shark are proteolytic intermediates present in the lysosomes. First, if that were the case, we should have observed a more varied number of smaller isoforms in our Western blots, which we did not. Second, we should have also observed varying and/or different amounts of proteins for all the isoforms; but we found almost equal and reproducible amounts of the full length $(32 \mathrm{kD})$ as well of the intermediate isoforms (28 and 25 $\mathrm{kD}$ ) throughout our Western blots.

\section{Glycosylation of Shark Po Isoforms}

The myelin Po protein is known to be heavily glycosylated [Uyemura et al., 1981], our finding of three different shark Po protein bands suggests that these might be due to different levels of glycosylation. To determine if this might be the case, we performed an Endoglycase F treatment on the myelin fraction to remove all the sugar residues from shark's myelin. A Western blot of this fraction showed that these 3 isoforms are fully glycosylated (fig. 3), as each band decreased equally by approximately $6 \%$ of their apparent molecular weight after deglycosylation, instead of becoming one single band of $25 \mathrm{kD}$. This finding suggests that the three different isoforms we observed might be due to products of different Po variants rather than differences in glycosylation.

\section{Regional Distribution of Po Isoforms}

The regional distribution of these Po isoforms in adult shark nervous system was studied similarly by doing Western blots from solubilized telencephalon, diencephalon, optic tectum, cerebellum and medulla. We found that these CNS regions share the three major isoforms $(25,28$ and $32 \mathrm{kD})$ also recognized by PoCyl in total pu-

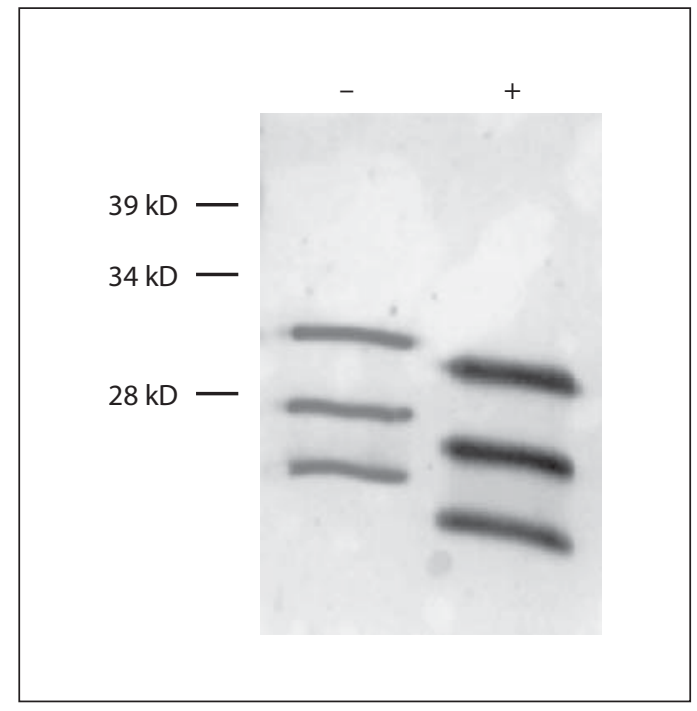

Fig. 3. Endo F treatment of myelin Po. Purified shark myelin was treated with an enzyme (EndoF) to remove all carbohydrates. Western blot showed that enzyme treated $\mathrm{Po}(+)$ isoforms run about $6 \%$ lower than fully glycosylated Po(-). A total of $4 \mu \mathrm{g}$ of protein from purified myelin was loaded on each lane.

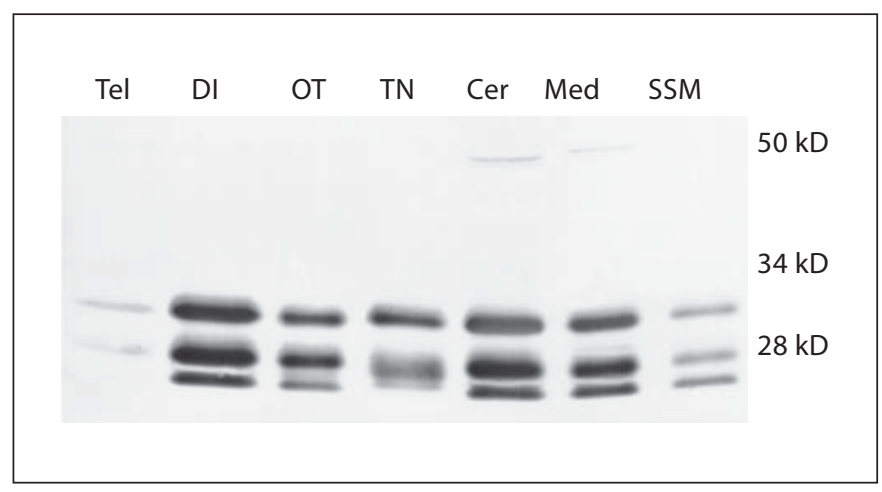

Fig. 4. Po isoform distribution in shark brain. Western blots with PoCyl from different brain regions showed that there was an unequal distribution of shark Po in different areas; $8 \mu \mathrm{g}$ of total brain lysates was prepared from dissected areas and ran on a SDS-PAGE gel. $\mathrm{Tel}=$ Telencephalon; $\mathrm{DI}=$ diencephalon; $\mathrm{OT}=$ optic tectum; $\mathrm{TN}=$ trigeminal nerve; Cer = cerebellum; Med = medulla; $\mathrm{SSM}=$ spinal cord myelin.

rified myelin (fig. 4). Using PoEx antibody showed only the two major bands in these samples, as with total purified shark myelin observed in figure 2 (data not shown). The telencephalon showed the lowest levels of Po, with faint amounts of the $25 \mathrm{kD}$ isoform, whereas cerebellum 


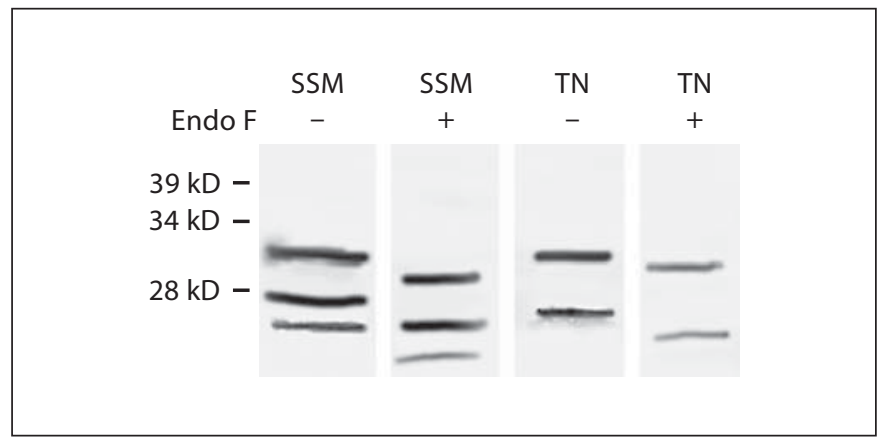

Fig. 5. Glycosylation of CNS and PNS shark myelin. Purified shark myelin $(5 \mu \mathrm{g})$ was treated with an enzyme to remove all carbohydrates (Endo F). Western blot showed that enzyme treated $\mathrm{Po}(+)$ isoforms run about $6 \%$ lower than fully glycosylated $\mathrm{Po}(-)$ for both CNS (SSM = shark spinal cord myelin) and PNS (TN = trigeminal nerve myelin). TN myelin showed only two of the three isoforms found in CNS.

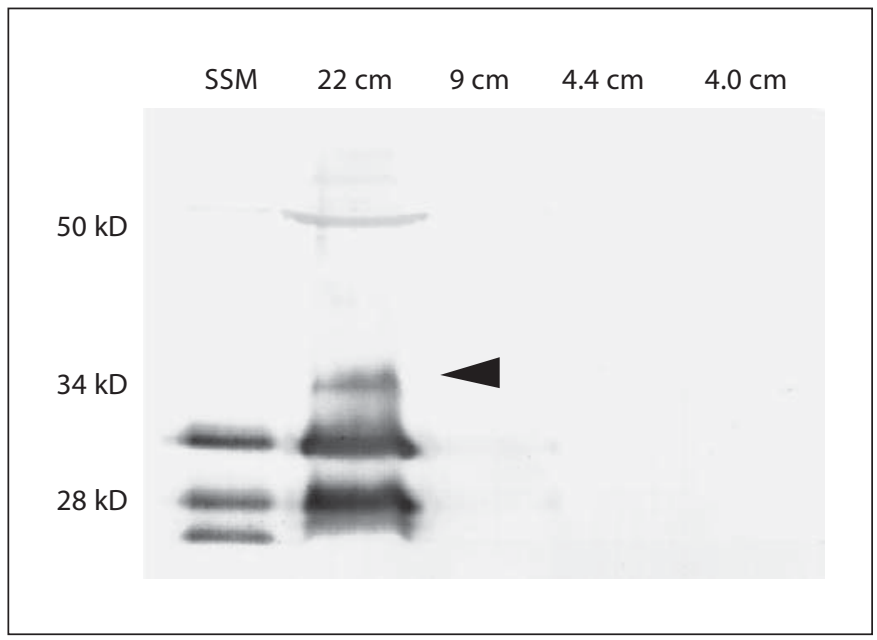

Fig. 6. Developmental expression of myelin Po. Shark brains from embryos at different developmental stages $(4,4.4,9$ and $22 \mathrm{~cm}$ embryos) were solubilized and run on an SDS-PAGE gel. Western blot was done with the PoCyl antibody that recognizes all three shark isoforms. Only the oldest embryo showed significant amounts of Po, and had three isoforms, the 32 and $28 \mathrm{kD}$ as well as a novel 34 $\mathrm{kD}$ (arrowhead). The total protein loaded was: $16 \mu \mathrm{g}$ of protein for the 4, 4.4 and $9 \mathrm{~cm}$ embryos, $4 \mu \mathrm{g}$ for the $22 \mathrm{~cm}$ embryo and $2 \mu \mathrm{g}$ for the positive control SSM (shark spinal cord myelin).

and diencephalon showed the highest levels of all three isoforms ( $\sim 50 \%$ higher than telencephalon).

We also looked at Po protein in shark PNS using the trigeminal nerve. We found that the expression of Po in the PNS is different from that in CNS. As shown in figure 5 , trigeminal nerve has a marked $32 \mathrm{kD}$ band and a second band running at $\sim 27 \mathrm{kD}$. In order to determine if it was due to different levels of glycosylation, we repeated the process of removing all the carbohydrates from the sample with EndoF. We observed that as expected for a fully glycosylated Po, the band ran 6\% lower after EndoF treatment although still at a clearly different weight compared with our standard myelin from spinal cord (fig. 5).

\section{Developmental Expression of Shark's Po Isoforms}

Finally, in order to find out if these distinct Po isoforms are regulated or equally expressed throughout development, whole brain from sharks at different stages of development were analyzed. Figure 6 shows Western blots of Squalus acanthias shark at embryonic stages of 4, $4.4,9$ and $22 \mathrm{~cm}$. Levels of Po glycoprotein were detectable only in the $22 \mathrm{~cm}$ embryos. We were able to observe only the 28 and $32 \mathrm{kD}$ isoforms, indicating that the $25 \mathrm{kD}$ isoform is not present during the initial stages of shark myelin formation. After over-exposure using ECL detection methods (Enhanced Chemiluminescence) we were able to observe that the $9 \mathrm{~cm}$ embryo had low levels of the 28 and $32 \mathrm{kD}$. A similar finding of fewer isoforms during development has been reported for trout larvae [Jeserich et al., 1990; Stratmann and Jeserich, 1995]. In addition, we observed a $34 \mathrm{kD}$ isoform in the $22 \mathrm{~cm}$ embryo (arrow in fig. 6), not present in adult shark brain after extensive over-exposures using Enhanced Chemiluminescence's detection (data not shown).

We further corroborated that Po is not found in the very early stages of shark development $(<5 \mathrm{~cm})$ by performing immunohistochemistry of shark embryo sections (embryos at $5 \mathrm{~cm}$ of a different species: Chiloscyllium punctatum) using a RatPo antibody that is capable of detecting Po in fixed tissue (fig. 7A, D, E; data for younger embryos, smaller than $5 \mathrm{~cm}$, not shown). The earliest time that we were able to immunostain for Po was in embryos at $5 \mathrm{~cm}$ stage) and onwards [Ballard, 1993]. In the youngest embryos we observed very few myelinated tracts, but in older embryos $(6 \mathrm{~cm})$ there were more Popositive fibers running laterally in the midbrain (fig. 7A, $\mathrm{D}, \mathrm{E})$. Meanwhile in the midbrain area there was robust and widespread neurofilament expression, this is a marker for mature neurons (fig. 7B). Because the staining for Po was not striking in these younger embryos, we performed immunostaining for myelin basic protein (MBP) another marker for myelination (fig. 7C). We noticed that MBP expression was detectable at earlier stages and in 
Fig. 7. Myelin protein expression in CNS of shark embryos. Immuno-histochemistry of $6 \mathrm{~cm}$ shark embryos showed that although myelination is not widespread in the CNS, there are distinguishable myelinated tracts in the shark embryo brain. $\mathbf{A}$ and $\mathbf{B}$ show the tectal region doublestained for Po (A) and beta-tubulin III (neuron specific, B), arrows point to myelinated fibers. Hindbrain regions close to the cerebellum (C, D) show fewer Po-positive fibers (D), than MBP in a consecutive section (C). Arrows point to the fibers positive for MBP and Po. Midbrain section at the level of the eye shows more Po-positive fibers as well as myelinated tracts reaching laterally (arrow). Arrowhead points to the trigeminal ganglia (E).
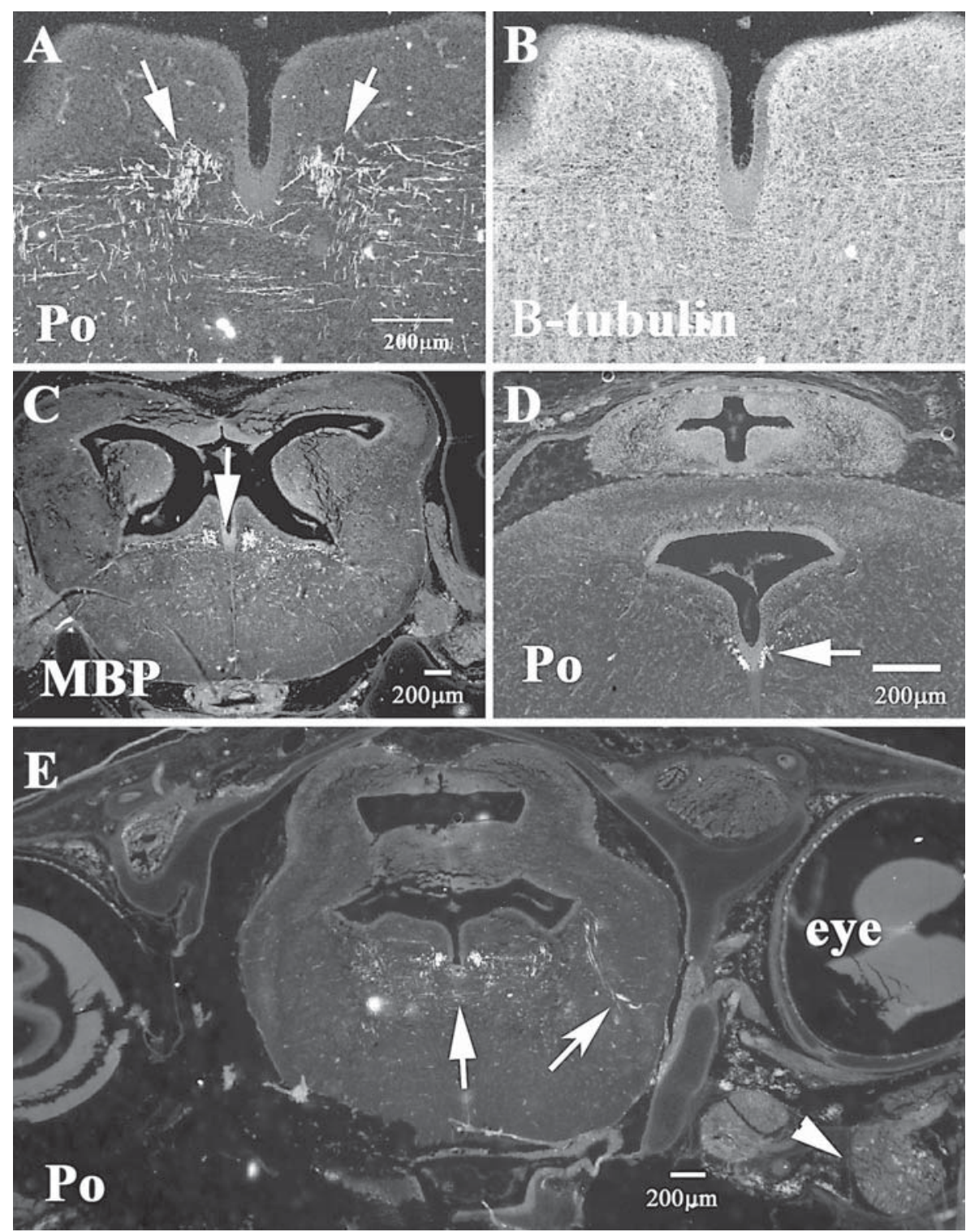

more fibers compared with Po in the Chiloscyllium embryos (compare fig. $8 \mathrm{C}$ with D). We were able to detect smaller amounts of Po and larger amounts of MBP in stage 32 spinal cords and hindbrain (fig. $8 \mathrm{D}$ and $\mathrm{A}$ ), suggesting that MBP expression might occur before Po. Later on in development $(7 \mathrm{~cm}$ embryos) we observed robust and comparable amounts of Po and MBP expression in the spinal cords of the embryos as well as in the PNS: ciliary ganglion, spinal nerves and sensory ganglions (fig. 8B, D, E, F).

\section{Discussion}

Research on non-mammalian myelin Po expression suggested the existence of two to four Po-like glycoproteins in shark and fish CNS [Tai and Smith, 1983, 1984; Saavedra et al., 1989]. Our study demonstrates for the first time that those shark glycoproteins, sometimes referred to as IP1-IP4 [Jeserich and Waehneldt, 1986], are indeed Po isoforms and that there is an additional isoform that was not considered Po in the past. We were able to establish this fact by the use of specific antibodies against shark's Po peptide sequences. 
Fig. 8. Myelin protein expression in spinal cord and ganglia embryos. Shark embryo sections $(3 \mathrm{~cm} \mathrm{A,} \mathrm{C,} \mathrm{D)} \mathrm{and} 7 \mathrm{~cm}(\mathbf{B}, \mathbf{E}, \mathbf{F})$ were immunostained for $\mathrm{MBP}(\mathbf{A}, \mathbf{C}$ and $\mathbf{E})$ or Po (B, D and $\mathbf{F})$ proteins. A corresponds to spinal cord at the vagal/medulla level, notice extensive MBP positive tracts (spinal cord ventral area in $\mathbf{A}$ ), but at the tail level there was none (C for MBP). Cranial ganglia myelination is more extensive and occurs more anteriorly (arrow in B). At the trunk levels (D), we observed Po-positive fibers in the ventral spinal cord but none in sensory ganglia (arrow). In older embryos (E and F) MBP and Po expression respectively was widespread and extensive, including spinal nerve (arrow in E) and ganglia (arrow in $\mathbf{F}$ ).
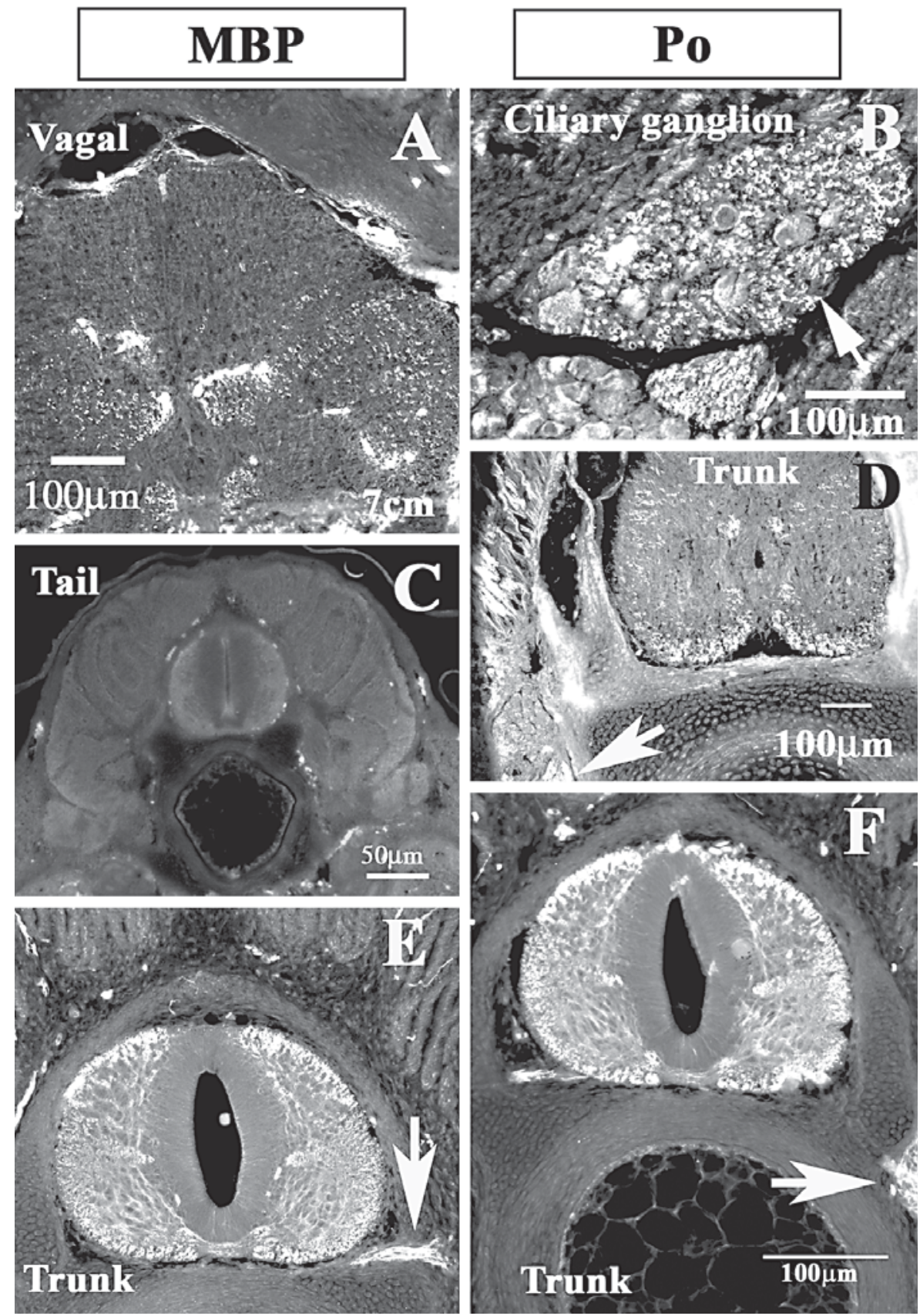

Previous studies showed that there were two Po isoforms in another elasmobranch species, the gummy shark (Mustelus antarcticus), but they did not identify the smallest, $25 \mathrm{kD}$ glycoprotein in whole brain extracts (likely IP4) as Po [Tai and Smith, 1984]. This discrepancy might be explained by: (a) the fact that we observed that this isoform is present in myelin at much lower amounts ( $~ 50 \%)$ than the other two; (b) that Tai and Smith did not use antibodies for the detection of these Po proteins in their blots and; (c) that they studied a carcharhiniform shark, which has a brain type different from the shark species we used, a squalomorph, that has a simpler laminar brain type. Although we used different shark species for immunohistochemical detection of Po and MBP during development, there is published and unpublished data with Mustelus canis, which indicates that in terms of 
expression of these proteins, the results are the same as the ones presented here [Gould, 1992; Gould et al., 1995]. Furthermore, Squalus (which we used for the Western blot analysis) is considered a primitive shark and Chiloscyllium (which we used for immunohistochemistry) is considered a more modern one. However, looking at their brains, the gross morphology is very different, e.g., the cerebellum of Squalus is smooth and Mustelus (a species more like Chiloscyllium) has a very convoluted brain. In spite of these overall differences, the cellular structures are quite similar and when we used Mustelus myelin, we got similar labeling.

The Po isoforms we detected in shark $(25,27,28$ and $32 \mathrm{kD}$ ) are fully glycosylated, as shown by their shift $(\sim 6 \%)$ in mobility in SDS gels, and are differentially expressed throughout the shark's nervous system. We found that samples from several CNS regions (telencephalon, diencephalon, optic tectum, cerebellum, medulla and spinal cord) all share the same three Po isoforms, whereas the PNS (trigeminal nerve) contains only the 27 and $32 \mathrm{kD}$. This two PNS bands are not the product of different degrees of glycosylation but rather suggests that at least in trigeminal nerve there may be a separate, distinct isoform of slightly lower molecular weight $(27 \mathrm{kD})$ than the second one $(28 \mathrm{kD})$ widely present in the CNS.

To date, only one Po mRNA transcript from shark was isolated from a cDNA library [Saavedra et al., 1989]. Our finding of several isoforms in the CNS and PNS from shark with different truncations has several explanations: that either these isoforms are due to differential splicing of Po mRNA transcripts; or that these isoforms are due to posttranslational modification of the full-length shark Po. Up until now the best characterized of the myelin Po proteins, besides mammalian, is the one in fish. In the trout researchers found only one mRNA [Stratmann and Jeserich, 1995]. At least two isoforms have been reported for another shark, though these reported isoforms do not have the same molecular weight as the ones reported in this paper [Tai and Smith, 1983, 1984; Zand et al., 1991]. In other words, elasmobranchs seem to have a series of proteolytically degraded forms of myelin Po that fish or mammals do not present.

All these results lead to the suggestion that Po undergoes proteolytical modification. This event is not uncommon and happens to be an effective mechanism of physiological regulation [Neurath, 1989]. It has been observed to occur at the cytoplasmic as well as extracellular N-terminus of several adhesion molecules and receptors [Ozawa and Kemler, 1990; Covault et al., 1991; O’Bryan et al.,
1995]. E-Cadherin adhesiveness requires a precise endogenous cleavage of a peptide at its $\mathrm{N}$-terminus domain [Ozawa and Kemler, 1990]. Slit2 is a well known chemorepellant molecule that is also proteolytically cleaved in the cell [Nguyen Ba-Charvet et al., 2001]. Moreover, there is evidence in sharks of post-translational modification of MBP [Deibler et al., 1975; Zand et al., 2001]. Thus, it is quite feasible that during myelination, different proteases might be activated that will modify the expression of Po as it happens for MBP. However, there is as yet no strong evidence towards a splice hypothesis or a proteolytic one.

The PNS and CNS myelin organization of cartilaginous and higher vertebrates depends on the same myelinating glial cells: oligodendrocytes for CNS and Schwann cells for the PNS [Bakay and Lee, 1966; Long et al., 1968; Schweigreiter et al., 2006]. However, the differentiated oligodendrocytes of mammals do not express Po at all but rather the PLP/DM20 glycoproteins [Milner et al., 1985]. Cartilaginous and bony fish have PLP/DM20like proteins [Kitagawa et al., 1993], but these proteins do not seem to play the role in myelin compaction that is observed in terrestrial vertebrates such as mammals [Boison et al., 1995; Yoshida and Colman, 1996]. Due to the high levels of Po in both PNS and CNS of non-mammalian vertebrates, it has been hypothesized that Po is responsible for myelin compaction in these organisms. However, at some point during evolution, between cartilaginous fish and reptiles, Po stopped being expressed in CNS, and PLP/DM20 came to play a major role in the myelin formation of higher vertebrates.

Our observations of several isoforms of Po with different truncations could shed some light on the change of role of Po, as well the 'phenotypically silent drop-out of Po from the terrestrial vertebrate CNS' [Yoshida and Colman, 1996]. Throughout evolution, protein modifications of Po in CNS myelin, such as the proteolytically cleaved products we present in this paper, could have made it less capable of sustaining compact myelin, allowing the adhesive PLP/DM20-like glycoproteins, already present as potential adhesive proteins, to take over that role in myelogenesis. Wong and Filbin have already shown that a truncated rat Po at its cytoplasmic terminus is incapable of supporting homophilic adhesion of transfected $\mathrm{CHO}$ cells and that, furthermore, it has a dominant negative effect on the adhesion of the full-length Po [Wong and Filbin, 1996]. The isoform of Po with such an effect is missing the same sequence recognized by the PoCy2 antibody. This sequence is absent as well in the 28 , 27 and $25 \mathrm{kD}$ isoforms in shark's Po. Maybe the post- 
translational modifications of full-length Po in elasmobranchs stripped it of its adhesive properties, leaving an open door for the PLP/DM20 protein to substitute for Po as the major adhesive molecule in the CNS. More than a 'silent drop' of Po as the major adhesive component in CNS myelin, it was a 'takeover' by the PLP/DM-20 molecules. It remains to be seen whether each of the identified isoforms of shark Po can support homophilic adhesion. The fact that this protein is so highly conserved throughout evolution suggests that those forms lacking the cytoplasmic domain might not support homophilic adhesion, or at least not in the same fashion as the fulllength protein.

The pattern for Po shown in this paper is very different from the one found in higher vertebrates, where Po is present only in the PNS, and only as a single isoform with slight variations in its levels of glycosylation. The current result of several Po isoforms, spatially and developmentally regulated, is a novel finding for this major myelin glycoprotein.

\section{Acknowledgements}

We give very special thanks to Marie T. Filbin and her lab members for their support when carrying out some of these experiments and for providing the specific shark antibodies used in these paper. We thank Cindy Malone and Sonsoles de Lacalle for useful discussions and Peter Rudy for technical assistance. This work was partly supported by an NIH-MBRS SCORE5S06GM048680-13.

\section{References}

Bakay L, Lee JC (1966) Ultrastructural changes Filbin MT, Walsh FS, Trapp BD, Pizzey JA, Tenin the edematous central nervous system. 3 . Edema in shark brain. Arch Neurol 14:644660. nekoon GI (1990) Role of myelin P0 protein as a homophilic adhesion molecule. Nature 344:871-872.

Ballard WW, Mellinger J, Lechenault H (1993) A Giese KP, Martini R, Lemke G, Soriano P, series of normal stages for development of Scyliorhinus canicula, the lesser spotted dogfish (Chondrichthyes: Scyliorhinidae). J Exp Zool 267:318-336.

-Boison D, Bussow H, D'Urso D, Muller HW, Stoffel W (1995) Adhesive properties of proteolipid protein are responsible for the compaction of CNS myelin sheaths. J Neurosci 15:5502-5513.

Bullock TH, Moore JK, Fields RD (1984) Evolution of myelin sheaths: both lamprey and hagfish lack myelin. Neurosci Lett 48:145148.

Butler AB, Hodos W (2005) Comparative Vertebrate Neuroanatomy : Evolution and Adaptation, 2nd ed. Hoboken, NJ: Wiley-Interscience.

Covault J, Liu QY, el-Deeb S (1991) Calcium-activated proteolysis of intracellular domains in the cell adhesion molecules NCAM and N-cadherin. Brain Res Mol Brain Res 11:1116.

D'Urso D, Brophy PJ, Staugaitis SM, Gillespie CS, Frey AB, Stempak JG, Colman DR (1990) Protein zero of peripheral nerve myelin: biosynthesis, membrane insertion, and evidence for homotypic interaction. Neuron 4: 449-460.

-Deibler GE, Martenson RE, Kramer AJ, Kies MW (1975) The contribution of phosphorylation and loss of $\mathrm{COOH}$-terminal arginine to the microheterogeneity of myelin basic protein. J Biol Chem 250:7931-7938.
Schachner M (1992) Mouse P0 gene disruption leads to hypomyelination, abnormal expression of recognition molecules, and degeneration of myelin and axons. Cell 71: 565-576.

Gould RM, Fannon AM, Moorman SJ (1995) Neural cells from dogfish embryos express the same subtype-specific antigens as mammalian neural cells in vivo and in vitro. Glia 15:401-418.

Gould RM, Morrison HG, Gilland E, Campbell RK (2005) Myelin tetraspan family proteins but no non-tetraspan family proteins are present in the ascidian (Ciona intestinalis) genome. Biol Bull 209:49-66.

Gould RM, Spivack WD, Gilland E, Pant HC, Tseng D (1992) Localization of myelin proteins in the developing shark spinal cord. Biol Bull 183:358-359.

Jeserich G, Waehneldt TV (1986) Characterization of antibodies against major fish CNS myelin proteins: immunoblot analysis and immunohistochemical localization of $36 \mathrm{~K}$ and IP2 proteins in trout nerve tissue. J Neurosci Res 15:147-158.

Jeserich G, Muller A, Jacque C (1990) Developmental expression of myelin proteins by oligodendrocytes in the CNS of trout. Brain Res Dev Brain Res 51:27-34.

Kirschner DA, Inouye H, Ganser AL, Mann V (1989) Myelin membrane structure and composition correlated: a phylogenetic study. J Neurochem 53:1599-1609.
Kitagawa K, Sinoway MP, Yang C, Gould RM, Colman DR (1993) A proteolipid protein gene family: expression in sharks and rays and possible evolution from an ancestral gene encoding a pore-forming polypeptide. Neuron 11:433-448.

Lemke G, Lamar E, Patterson J (1988) Isolation and analysis of the gene encoding peripheral myelin protein zero. Neuron 1:73-83.

Long DM, Bodenheimer TS, Hartmann JF, Klatzo I (1968) Ultrastructural features of the shark brain. Am J Anat 122:209-236.

Milner RJ, Lai C, Nave KA, Lenoir D, Ogata J, Sutcliffe JG (1985) Nucleotide sequences of two mRNAs for rat brain myelin proteolipid protein. Cell 42:931-939.

Neurath H (1989) Proteolytic processing and physiological regulation. Trends Biochem Sci 14:268-271.

Nguyen Ba-Charvet KT, Brose K, Ma L, Wang $\mathrm{KH}$, Marillat V, Sotelo C, Tessier-Lavigne M, Chedotal A (2001) Diversity and specificity of actions of Slit2 proteolytic fragments in axon guidance. J Neurosci 21:4281-4289.

Norton WT, Poduslo SE (1973) Myelination in rat brain: method of myelin isolation. J Neurochem 21:749-757.

Nunn DJ, LeBlanc AC, Mezei C (1987) A 42 K protein of chick sciatic nerve is immunologically related to PO protein of peripheral nerve myelin. Neurochem Res 12:377-384.

O’Bryan JP, Fridell YW, Koski R, Varnum B, Liu ET (1995) The transforming receptor tyrosine kinase, $\mathrm{Axl}$, is post-translationally regulated by proteolytic cleavage. J Biol Chem 270:551-557.

DOzawa M, Kemler R (1990) Correct proteolytic cleavage is required for the cell adhesive function of uvomorulin. J Cell Biol 111: 1645-1650. 
-Saavedra RA, Fors L, Aebersold RH, Arden B, Horvath S, Sanders J, Hood L (1989) The myelin proteins of the shark brain are similar to the myelin proteins of the mammalian peripheral nervous system. J Mol Evol 29:149156.

-Sauka-Spengler T, Meulemans D, Jones M, Bronner-Fraser M (2007) Ancient evolutionary origin of the neural crest gene regulatory network. Dev Cell 13:405-420.

-Schweigreiter R, Roots BI, Bandtlow CE, Gould RM (2006) Understanding myelination through studying its evolution. Int Rev Neurobiol 73:219-273.

-Stratmann A, Jeserich G (1995) Molecular cloning and tissue expression of a cDNA encoding IP1-a P0-like glycoprotein of trout CNS myelin. J Neurochem 64:2427-2436.

-Tai FL, Smith R (1983) Shark CNS myelin contains four polypeptides related to the PNS protein Po of higher classes. Brain Res 278: 350-353.
Tai FL, Smith R (1984) Comparison of the major proteins of shark myelin with the proteins of higher vertebrates. J Neurochem 42:426433.

Uyemura K, Kitamura K (1991) Comparative studies on myelin proteins in mammalian peripheral nerve. Comp Biochem Physiol C 98:63-72.

Uyemura K, Horie K, Suzuki M, Kitamura K (1981) Glycosylation of myelin glycoproteins in peripheral nerve via lipid intermediates. Neurochem Res 6:959-968.

Waehneldt TV (1990) Phylogeny of myelin proteins. Ann NY Acad Sci 605:15-28.

Waehneldt TV, Matthieu JM, Stoklas S (1987) Immunological evidence for the presence of myelin-related integral proteins in the CNS of hagfish and lamprey. Neurochem Res 12: 869-873.

Waehneldt TV, Stoklas S, Jeserich G, Matthieu JM (1986) Central nervous system myelin of teleosts: comparative electrophoretic analysis of its proteins by staining and immunoblotting. Comp Biochem Physiol B 84:273278 .
Wischnitzer S (1993) Atlas and Dissection Guide for Comparative Anatomy, 5th. ed. New York: W.H. Freeman and Co.

Wong MH, Filbin MT (1996) Dominant-negative effect on adhesion by myelin Po protein truncated in its cytoplasmic domain. J Cell Biol 134:1531-1541.

Yoshida M, Colman DR (1996) Parallel evolution and coexpression of the proteolipid proteins and protein zero in vertebrate myelin. Neuron 16:1115-1126.

Zand D, Hammer J, Gould R, Quarles R (1991) High expression of the HNK-1/L2 carbohydrate epitope in the major glycoproteins of shark myelin. J Neurochem 57:1076-1079.

Zand R, Jin X, Kim J, Wall DB, Gould R, Lubman DM (2001) Studies of posttranslational modifications in spiny dogfish myelin basic protein. Neurochem Res 26:539-547. 